\title{
Significance of Local Taxes in Income Structure of Slovak Municipalities
}

\author{
Gál Marián, Ing. Ph.D. \\ Faculty of Economics, Department of Finance, Technical University of Košice, Slovakia \\ marian.gal@tuke.sk \\ Tóth Peter, Ing. \\ Faculty of Economics, Department of Finance, Technical University of Košice, Slovakia \\ peter.toth@tuke.sk
}

\section{Doi:10.5901/mjss.2015.v6n3p544}

\begin{abstract}
Paper focuses on public revenues of municipalities and analyses the importance and significance of local taxes for the Slovak municipalities. Eight municipalities representing the capital cities of higher territorial units in Slovakia were selected. The aim of the paper is to estimate relationship between two tax decentralization measures (local tax income / current revenues and local tax income / total revenues) on one side and number of the citizens, city unemployment and average salary on the other one. We aim to determine and examine the importance and significance of local taxes for the municipalities. Hypothesis: The share of local taxes on total incomes is above 20\%. The overall analysis and conclusions were provided for the period 2010-2013. We used three different methods to reach objectives: synthesis of information to give literature background, analytical methods with econometric models to calculate data, and comparison of obtained results. Recommendations of future actions for municipalities are also included.
\end{abstract}

Keywords: local taxes, municipalities, incomes, econometric models.

\section{Introduction}

Local taxes are one of the taxation revenues collected by municipalities in Slovakia. They represent special group of citizen taxation. They are determined by municipalities and they flow directly to their budgets. In Slovakia, we distinguish eight voluntarily local taxes and one compulsory local fee. They all are defined in an Act 582/2004 on local taxes and local fee for communal waste. Municipalities have a free choice depending on their requirements, size, number, and amount of provided public goods and services to implement these local taxes. Local fee for communal waste is the only compulsory local tax set by municipality. Municipalities have also right to administer these taxes, to set tax rates and subject of taxation, or to decide on exemptions from payment. Usually, bigger municipalities adopt all local taxes.

Recently, after decentralisation of competences in 2001 and fiscal decentralisation in 2004 in Slovakia, the significance and importance of local taxes has grown. Municipalities have become more independent from state government and subjective decisions of state representatives. Total local taxes oscillate between $20-25 \%$ of all municipality incomes. Local taxes belong together with shared Income tax from natural persons to own incomes.

The aim of the paper is to estimate relationship between two tax decentralization measures (local tax income I current revenues and local tax income / total revenues) on one side and number of the citizens, city unemployment and average salary on the other one. We aim to analyse and determine the importance and significance of local taxes for the municipalities. We stated hypothesis: The share of local taxes on total incomes is above $20 \%$. For our purpose, we selected eight municipalities representing the capital cities of higher territorial units in Slovakia. We picked the period of 2010-2013. The presented analysis is based on some three variants of the panel data models - pooling model (PM), fixed effects model (FEM) and random effects model (REM). We analysed the development of local taxes within focused period, compared obtained data with both current and total incomes, and finally we confronted obtained results with stated hypothesis and gave further recommendations to analysed municipalities.

Paper is divided into five chapters. Chapter 2 provides information on objectives and research methods used to prove/decline stated hypothesis. In general, we provided synthesis of relevant expert and scientific literature sources from domestic and foreign literature. In Chapter 4, we applied the econometric models, analytical methods and comparison of obtained data. Literature overview and present state of problematic are part of Chapter 3. We identified up-to-date 
definitions, characteristics and opinions on local taxes and their position and role in income structure of the Slovak municipalities. The analyses and discussions of local taxes development in selected municipalities and for selected period are part of Chapter 4. Final conclusions and recommendations for municipalities are involved in Chapter 5.

\section{Objectives and Research Methodology}

The aim of the paper is to estimate relationship between two tax decentralization measures (local tax income / current revenues and local tax income / total revenues) on one side and number of the citizens, city unemployment and average salary on the other one. We stated hypothesis: The share of local taxes on total incomes is above $20 \%$. In order to fulfil given objective we used the following methods:

1. Synthesis of information and available data to offer literature overview of focused topic and present state of problematic. We collected information from scientific and expert domestic and foreign literature sources, the Slovak Statistic Office, from budgets and internal financial statements of selected municipalities, web portal of the Slovak municipalities, as well as from the Internet sources.

2. Analytical methods were applied in Chapter 4 . We analysed data from budget incomes in order to calculate the development of local taxes in 2010-2013. We chose eight Slovak municipalities representing the capital cities of higher territorial units. Data were collected from final accounting closing reports and thus they express real obtained financial sources.

3. We calculated local taxes and summed the incomes from all kinds of local taxes collected by municipalities. The share of local taxes on current revenues was calculated: income from local taxes

total current revenues

The aim is to determine the significance of local taxes for current revenues and current spending. The share of local taxes on total revenues was calculated: income from local taxes

total revenues

The aim is to determine the significance of local taxes for the municipality and to confirm/decline stated hypothesis.

4. The presented analysis is based on some three variants of the panel data models - pooling model (PM), fixed effects model (FEM) and random effects model (REM). The general linear relationship is defined as follows:

$y_{i t}=\alpha+\beta^{T} \mathbf{x}_{i t}+\mu_{i}+\lambda_{t}+\epsilon_{i t}$

where $y_{i t}$ is a discussed decentralization measure as dependent variable, $\mathbf{x}_{i t}$ is a vector of explanatory variables (number of citizens, city unemployment and average salary), $\mu_{i}$ and $\lambda_{t}$ represent individual error components and $\epsilon_{i t}$ is idiosyncratic error independent of regressors $\mathbf{x}_{i t}$. Indices $i$ and $t$ specify city and time, respectively. If individual error components are statistically insignificant, PM provides unbiased and efficient estimation. On the other side, in case the individual error components are correlated with any of the explanatory variables, then PM and REM provide biased estimations. In this case, the FEM specification is needed. REM is most appropriate, if there are statistically significant individual components but uncorrelated with any of the explanatory variables. In order to distinguish the above given regimes, we applied the Poolability $F$ test of the statistical significance of the individual components. To decide between the REM and FEM, we use the Hausman (1978) testing methodology based on consistency of the fixed and the random effects models.

Analysis was done in the $\mathrm{R}$ ( $\mathrm{R}$ Development Core Team, 2014) using package plm (Croissant et al., 2013).

5. Comparison of obtained figures, data, and shares of local taxes on both current and total municipalities' incomes. Analysis of correlation of local taxes with current and total incomes. Provided comparison and analysis of correlation will enable us to prove or decline stated hypothesis.

\section{Literature Overview}

Act 582/2004 on local taxes and local fee for communal waste defines following eight voluntarily local taxes and one compulsory fee:

- property tax,

- tax for dog ownership,

- tax for using of public space,

- tax from accommodation, 
- tax from vending machines,

- tax from selling automats,

- tax for entry and stay with motor vehicle in historic part of the city,

- tax for nuclear facility,

- fee from communal waste as compulsory local tax.

The virtues of the local taxes that have given rise to their importance have been long recognised by public finance scholars. As Brunori, Green, Bell, Choi, and Yuan (2006) point out, the local taxes have been praised by the intellectual leaders in the public finance field as the ideal source of revenue for local governments. And there is virtual unanimity amongst these and other scholars as to the virtues of the taxes. That leading scholars have touted the virtues of the local taxes have led to widespread endorsement of the taxes by public finance professionals. As public finance experts recognise, the local taxes revenue has consistently grown over the years. As importantly, from a political perspective, the local taxes revenue grows without the risks associated with raising rates.

Slemrod (1995) set several reasons for the success of these taxes:

1. The property tax remains an important source of revenue for local governments in large part because it has always played that role. The historical dominance of the tax was attributable to the fact that there were no alternatives to financing local government. Just fiscal decentralisation provided in 2004 in Slovakia, brought further opportunities for municipalities to collect own sources and thus to increase own independence from state government.

2. The property tax has long provided a stable and reliable source of revenue for local governments. Local governments rely on the tax because, unlike all other local option taxes, the base of the tax cannot, for all intents and purposes, be moved. Property tax rates are rarely raised to meet the public service demands of the citizens. Indeed, property tax revenue often grows faster than the public service demands of local citizens. According to Sokolow (1998), the property tax is the principle source of fiscal flexibility for local governments.

3. Sheffrin (1999) points out that the administration and compliance with the property tax is relatively easy and thus inexpensive. For government, the tax base is easily identifiable. And while values change, the number of acres, parcels, and buildings are easily ascertainable by most local government administrators. Another virtue from the government's perspective is that taxpayers cannot easily hide or move property. The property tax is thus difficult to evade. Youngman (1999) argues that industrial property taxation is also politically attractive and thus likely to continue because officials and the public view the business taxes as "victimless" because they fall on corporations or are exported.

4. The property tax has endured because it is conceptually attractive. Property tax revenue is raised locally to support local public services. That connection arises because the services provided by local governments benefit the owners and renters of the property within the jurisdiction. Fischel (2001) agrees that the property, the taxes, and the services are all linked. That is why local governments pursue policies that protect and increase the value of property located in their jurisdictions, particularly the value of residential property.

We agree with the opinion of Sotolár (2004) that reasons why state transfers its significant competence in the area of local taxes on municipalities relies on their rationality, effectiveness, suitability, and logic. As Neubauerová (2009) states that although there are some countries transferring the revenues from income or consumption taxes to local budgets, in general the local and property taxes remain the most frequent ones administered by municipalities. She emphasises their positive characteristics: comparing to income taxes they influence the labour effort the least.

Široký (2008) notices the stable and easily defined and identifiable revenue of local taxes. He identifies the following principles of local taxes: (1) local governments must have a competence and authority to implement or to postpone the local taxes; (2) local governments must be obliged to decide on tax rate, tax base, subject of taxation, tax payers, and on tax exemptions; (3) local taxes must be originally administered and directed to municipal budgets without any opportunity of national government to withdraw any revenues; (4) local taxes must result from local sources such as local property situated within the municipality jurisdiction.

Taxes with stable tax base should be the revenues of local budgets. At once, these taxes should be difficult to avoid, tax evasions should be minimised, and the whole taxation revenue should remain in municipal budgets.

Frees, E. W. (2004) focused on models and data that arise from repeated measurements taken from a crosssection of subjects which is referred as panel data. Croissant, Y.; Millo, G. (2008) described estimation of linear panel model in $\mathrm{R}$.

Maličká et al. (2012) used panel data analysis to measure the influence of the fiscal decentralization on public debt in the member states of the European Union. Geys, Revelli (2009) investigated the economic and political determinants 
of the local tax mix using panel data.

\section{Analysis of Local Taxes in Selected Municipalities}

The Chapter 4 deals with the analysis of significance and importance of local taxes for Slovak municipalities. For our purposes, we chose municipalities of Bratislava, Trnava, Trenčín, Nitra, Žilina, Banská Bystrica, Prešov, and Košice. We obtained required data from the internal accounting statements of municipalities as well as from their budgets. We calculated indicators in the way described in Chapter 2 - Objectives and Research methodology.

\subsection{Description of municipalities}

The Chapter 4.1 gives a brief description of selected municipalities. We provided readers with basic demographical and economic indicators. As seen from Table 1, Bratislava as the capital city of Slovakia is the most economically developed municipality. The second biggest one is Košice situated in the Eastern Slovakia. The remaining capital cities of higher territorial units are approximately the same concerning the economic fundamentals (with Prešov exemption) and number of inhabitants (with exemption of Trenčín).

Table 1: Characteristics of selected municipalities

\begin{tabular}{|c|c|c|c|c|}
\hline Municipality & Inhabitants (thousand) & Acreage $\mathbf{( k m}^{2}$ ) & Average unemployment (\%) & Average salary (€) \\
\hline Bratislava & 414 & 367,58 & 5,20 & 1220 \\
\hline Trnava & 67 & 71,54 & 7,22 & 865 \\
\hline Trenčín & 57 & 82 & 8,65 & 857 \\
\hline Nitra & 81 & 100,50 & 9,84 & 839 \\
\hline Žilina & 85 & 80,03 & 10,07 & 863 \\
\hline Banská Bystrica & 79 & 103,37 & 9,86 & 818 \\
\hline Prešov & 92 & 70,4 & 18,15 & 756 \\
\hline Košice & 241 & 244 & 11,25 & 880 \\
\hline
\end{tabular}

Source: Statistic office and internal municipality financial statements.

\subsection{Analysis of local taxes in 2010 - 2013 in selected municipalities}

In Chapter 4.2 we analyse the development of local taxes in selected Slovak municipalities and their share on both current and total incomes.

Table 2 summarises obtained financial sources from all local taxes the municipalities adopted. Data were collected from municipalities' final closing reports.

Table 2: Development of local taxes in selected municipalities (in €)

\begin{tabular}{|c|c|c|c|c|c|}
\hline Year Municipality & $\mathbf{2 0 1 0}$ & $\mathbf{2 0 1 1}$ & $\mathbf{2 0 1 2}$ & $\mathbf{2 0 1 3}$ & Index 2013/2010 (\%) \\
\hline Bratislava & 52258516 & 52587200 & 56416907 & 56519197 & 108.15 \\
\hline Trnava & 8831951 & 9109275 & 10329961 & 10740924 & 121.61 \\
\hline Trenčín & 6469479 & 6620606 & 7601768 & 7775730 & 120.19 \\
\hline Nitra & 9965011 & 10594269 & 11328585 & 11288277 & 113.28 \\
\hline Žilina & 8697816 & 8845117 & 11657256 & 12804140 & 147.21 \\
\hline Banská Bystrica & 7997954 & 8278508 & 9844778 & 10603518 & 132.58 \\
\hline Prešov & 6908733 & 6947742 & 8862709 & 8738894 & 126.49 \\
\hline Košice & 30286583 & 31846471 & 31230708 & 36686786 & 121.13 \\
\hline \multicolumn{6}{|c|}{ Average Index 123.83 } \\
\hline
\end{tabular}

Source: Own calculation on a basis of municipality budgets and closing reports.

There are two most important local taxes for Slovak municipalities: property tax and fee for communal waste. They contribute to overall incomes from local taxes by more than $90 \%$ (property tax is the highest financial source for 
municipalities). As seen from Table 5, in almost all municipalities the income from local taxes has constantly grown within the analysed period. The few exemptions can be found in municipality of Košice in 2012 (slight decrease), and in Nitra and Prešov (2013), respectively. These increases in local tax incomes were caused mainly by increased tax rates from property taxes and tax from communal waste, slightly from increased population, as well as from improved economic fundamentals. Although we also noticed increased tax rates in other taxes, they did not bring any significant income to municipalities. Despite of constant increase in property tax rates, there is still free space for their potential growth and for strengthening of their share within the income structure. And that is what municipalities have successfully done: Index 2013/2010 in final column of Table 2 expresses the growth rate and significance of income from local taxes for them. The highest growths were noticed in Žilina, Banská Bystrica and Prešov. City of Košice also increased local tax rates significantly in 2013 in order to fulfil gap in incomes. Obtained data point out to strengthen significance of local taxes for municipality representatives.

These data are expressed in absolute numbers, though. We see the rise of the importance of local taxes for municipalities as they contribute to widen scale of provided public services. The higher income from local taxes municipalities receive, the bigger volume of public services they offer. But what these figures do not say to us? The purpose of the paper was not to show sole development of local taxes. The aim is to show how important they are for municipalities in order to become independent from state decisions and to decrease own indebtedness. For these purposes, we also calculated and analysed the share of local taxes on both current and total revenues.

Table 3: Share of local taxes on current revenues in selected municipalities (in \%)

\begin{tabular}{|c|c|c|c|c|c|}
\hline Year Municipality & $\mathbf{2 0 1 0}$ & $\mathbf{2 0 1 1}$ & $\mathbf{2 0 1 2}$ & $\mathbf{2 0 1 3}$ & Average share \\
\hline Bratislava & 28.62 & 26.51 & 39.11 & 26.44 & 30.17 \\
\hline Trnava & 24.88 & 24.54 & 26.32 & 26.23 & 25.49 \\
\hline Trenčín & 24.18 & 23.22 & 25.34 & 24.77 & 24.76 \\
\hline Nitra & 25.24 & 25.19 & 25.26 & 24.80 & 25.27 \\
\hline Žilina & 17.77 & 19.03 & 23.84 & 25.68 & 21.58 \\
\hline Banská Bystrica & 21.34 & 20.84 & 23.16 & 24.16 & 22.38 \\
\hline Prešov & 14.13 & 14.47 & 17.43 & 16.65 & 15.67 \\
\hline Košice & 27.11 & 26.67 & 26.29 & 28.53 & 27.15 \\
\hline Total Average Share 24.06 & \multicolumn{5}{l}{} \\
\hline
\end{tabular}

Source: Own calculation on a basis of municipality budgets and closing reports.

The second step was to analyse the share of local taxes on current revenues. Current revenues consist of both taxation and non-taxation revenues. Slovak municipalities receive two kinds of taxation revenues: shared Income tax from natural persons (comprising $60-65 \%$ of current revenues) and local taxes. Non-taxation revenues are represented by items such as administrative fees, property rental income, received interests, fines, and many others.

Table 3 shows that local taxes have stable position within the current revenues and are important income source for municipalities. According to absolute numbers in Table 2, local taxes intent to grow every year and thus indicate the same behaviour and attitude of municipality representatives towards significance of local taxes. After calculating the share of local taxes on current revenues we found more differences. In cities of Bratislava, Trnava, Trenčín, Nitra, and Košice the share of local taxes on current revenues oscillates around or above $25 \%$ what confirms the need of local taxes and their importance for local budgets. On the other hand, the share of local taxes on current revenues in other three remaining cities (Žilina, Banská Bystrica and Prešov) is below 25\% what means that municipalities are more dependent on shared income tax and state subsidies in financing of current spending. Representatives of these three municipalities realise the necessity of own revenues and therefore they increased property tax as well as communal waste rates in order to strengthen their budgets. We see that the share of local taxes also grew in 2012-2013 in other three cities.

Intention to increase both absolute number of local taxes and their share on current revenues is highly recommend. 
Table 4: Share of local taxes on total revenues in selected municipalities (in \%)

\begin{tabular}{|c|c|c|c|c|c|}
\hline Year Municipality & $\mathbf{2 0 1 0}$ & $\mathbf{2 0 1 1}$ & $\mathbf{2 0 1 2}$ & $\mathbf{2 0 1 3}$ & Average share \\
\hline Bratislava & 19.01 & 18.88 & 26.73 & 24.55 & 22.29 \\
\hline Trnava & 19.37 & 21.81 & 20.08 & 23.08 & 21.09 \\
\hline Trenčín & 18.72 & 16.32 & 18.64 & 21.56 & 18.81 \\
\hline Nitra & 14.65 & 17.99 & 20.13 & 17.68 & 17.61 \\
\hline Žlina & 13.95 & 11.86 & 23.29 & 24.76 & 18.47 \\
\hline Banská Bystrica & 18.58 & 19.94 & 18.23 & 22.08 & 19.71 \\
\hline Prešov & 12.53 & 12.46 & 15.84 & 16.07 & 14.23 \\
\hline Košice & 20.52 & 20.68 & 21.98 & 19.08 & 20.57 \\
\hline \multicolumn{7}{|c|}{ Total Average Share 19.10 } \\
\hline
\end{tabular}

Source: Own calculation on a basis of municipality budgets and closing reports.

Table 4 illustrates the share of local taxes on total municipality incomes. From given data we should be able to confirm or decline our hypothesis. It is not easy to make strict conclusion, though. Total incomes consist not only from current ones, but also from capital incomes and the one from financial operations such as received bank loans or transfers from municipality funds. Municipalities receive capital incomes or bank loans to build new infrastructure or to reconstruct and modernise the persisting one. And that is what happened in some analysed municipalities within 2010-2013. Bratislava increased its indebtedness by accepting bank loans in order to support huge reconstruction of the municipal ice-hockey stadium because of the IIHF World Championship held in Slovakia in 2011. So did Žilina. They received state loans to purchase land for the automobile factory in 2010-2011. The same occurred in Košice: they obtained EU and state grants over 70 mills. $€$ for reconstructing and renovating the cultural facilities connected with the European Capital of Culture 2013 title. All these capital spending meant that the share of local taxes on total revenues dropped despite of their constant growth in absolute numbers and even despite the growth of their share on current revenues. It is caused by higher capital inflows to the budgets. On the other hand, municipalities with lower indebtedness and capital spending noticed significant growth of the share of local taxes on total revenues. That clearly indicates that they have become more important for municipalities. As the average share of local taxes on total revenues exceeds $20 \%$ we can point out to their importance.

Our panel seemingly suffers by the significant correlations between the explanatory variables, which can cause the multi-collinearity problem inducing large standard errors of the estimated regression coefficients; however the coefficient of determination achieves relatively high values. Therefore, we introduce the estimated Pearson correlations given in Table 5. The highest correlation was indicated in the case of the relation between number of inhabitants and average salary. Average salary is highly correlated with unemployment, too. That is why we exclude the salary variable in further analysis.

Table 5: Correlation Matrix

\begin{tabular}{|c|c|c|c|}
\hline & inhabitants & unemployment & salary \\
\hline inhabitants & $1.000^{\star \star *}$ & $-0.399^{\star \star}$ & $0.830^{\star \star \star}$ \\
\hline unemployment & $-0.399^{\star \star}$ & $1.000^{\star \star \star}$ & $-0.638^{\star \star \star}$ \\
\hline salary & $0.830^{\star \star *}$ & $-0.638^{* \star *}$ & $1.000^{* \star *}$ \\
\hline
\end{tabular}

Note: ${ }^{* \star \star},{ }^{\star \star},{ }^{*}$ denote significance levels on 1, 5 and 10 percent respectively.

Figure 1 shows evolution of the dependent variables across cities. There is noticeable rise over time in both variables. 


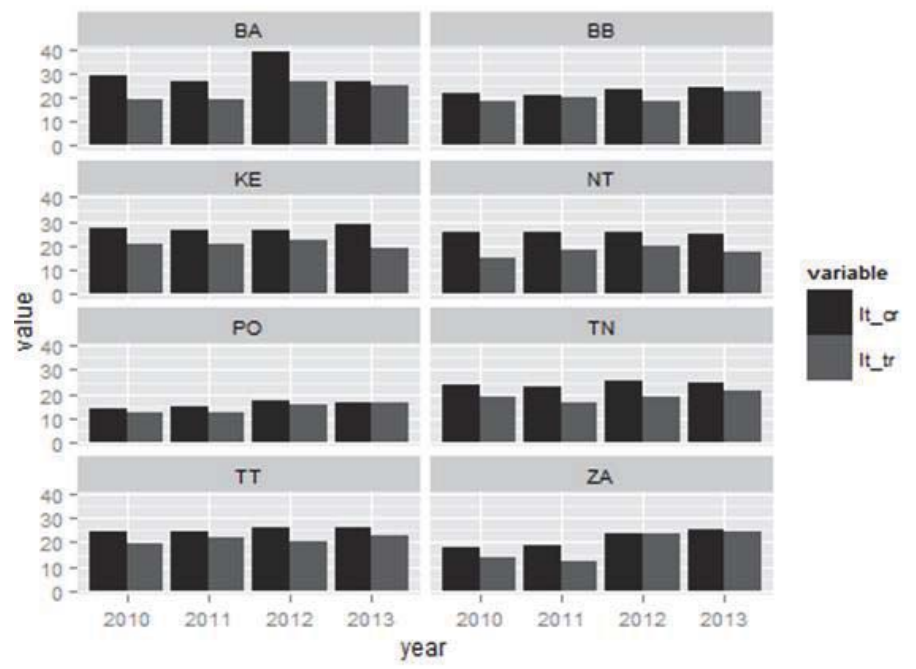

Figure 1: Evolution of dependent variables accross cities

Note: It_cr is share of local taxes on current revenues and It tr is share of local taxes on total revenues.

We estimated four linear panel models with both dependent variables share of local taxes on current revenues and share of local taxes on total revenues.

Table 6: Estimated coefficients for dependent variable share of local taxes on current revenues

\begin{tabular}{|c|c|c|c|c|}
\hline & $\begin{array}{c}\text { Fixed effects } \\
\text { overparameterized model (1) }\end{array}$ & $\begin{array}{c}\text { Pooling parsimonious } \\
\text { Model (2) }\end{array}$ & $\begin{array}{c}\text { Fixed effects } \\
\text { parsimonious model } \\
(3)\end{array}$ & $\begin{array}{c}\text { Random effects } \\
\text { parsimonious model } \\
(4)\end{array}$ \\
\hline intercept & Estimate & Estimate & Estimate & Estimate \\
\hline No. inhabitants & - & $0.29645^{\star \star \star}$ & - & $0.30715^{\star \star \star}$ \\
\hline unemployment & $0.00003^{\star \star *}$ & $0.00001^{\star \star}$ & $0.00001^{\star \star \star}$ & $0.00001^{\star \star \star}$ \\
\hline salary & $-1.29490^{\star \star *}$ & $-0.79681^{\star \star *}$ & $-0.91170^{\star \star \star}$ & $-0.89583^{\star \star \star}$ \\
\hline R-Squared & $-0.02557^{\star}$ & - & - & - \\
\hline
\end{tabular}

Note: ${ }^{* * *},{ }^{* *},{ }^{*}$ denote significance levels on 1,5 and 10 percent respectively. Poolability test for individual cross-sectional effects using fixed effects model predicts that all coefficients, excluding the intercepts are equal for individual effects $(F=0.2664)$ and time effects $(F=0.3347)$. $F$ test for individual effects suggests statistically insignificant difference among individuals ( $\mathrm{F}=1.9895)$. On the other side, $\mathrm{F}$ test for time effects indicates statistically significant difference among individual time components $\left(\mathrm{F}=5.8396^{\star \star *}\right)$. Parsimonious FEM uses time dummies. Overparameterized FEM (1) contains full vector of independent variables including salary. Parsimonious models (2), (3), (4) exclude salary as a regressor. Hausman test (Chisquared $=0.4676$ ) favors application of the parsimonious FEM (3).

Estimate of the regression coefficient of the number of inhabitants' variable is positive. It means that it has positive impact on share of local taxes on current revenues. Negative sign by the estimated regression coefficient of unemployment means that higher unemployment implies local tax income reduction.

The same analysis was realized for dependent variable share of local taxes on total revenues. Estimated regression coefficient for number of inhabitants is not statistically significant in that case. The best model (3), according to Hausman test, predicts negative impact of unemployment on share of local taxes on total revenues. 
Table 7: Estimated coefficients for dependent variable share of local taxes on total revenues

\begin{tabular}{|c|c|c|c|c|}
\hline & $\begin{array}{c}\text { Fixed effects } \\
\text { overparameterized model (1) }\end{array}$ & $\begin{array}{c}\text { Pooling parsimonious } \\
\text { Model (2) }\end{array}$ & $\begin{array}{c}\text { Fixed effects } \\
\text { parsimonious model (3) }\end{array}$ & $\begin{array}{c}\text { Random effects parsimonious } \\
\text { model (4) }\end{array}$ \\
\hline & Estimate & Estimate & Estimate & Estimate \\
\hline intercept & - & $0.22180^{\star \star \star}$ & - & $0.23337^{\star \star \star}$ \\
\hline inhabitants & 0.00000 & 0.00000 & 0.00000 & -0.00000 \\
\hline unemployment & $0.48595^{\star}$ & $-0.42161^{\star \star}$ & $-0.54288^{\star \star \star}$ & - \\
\hline salary & 0.00380 & - & - & 0.44364 \\
\hline R-Squared & 0.44628 & 0.27235 & 0.47351 & - \\
\hline
\end{tabular}

Note: ${ }^{* * *},{ }^{* *},{ }^{*}$ denote significance levels on 1,5 and 10 percent respectively. Poolability test for individual cross-sectional effects using fixed effects model predicts the same results for both effects, for individual effects ( $F=0.9203)$ and time effects $(F=0.3355)$. $F$ test for individual effects suggests statistically insignificant difference among individuals ( $F=1.8237)$. On the other side, $\mathrm{F}$ test for time effects indicates statistically significant difference among individual time components $\left(\mathrm{F}=7.2431^{* \star *}\right)$ as well as in the previous analysis. Parsimonious FEM uses time dummies. Overparameterized FEM (1) contains full vector of independent variables including salary. Parsimonious models (2), (3), (4) exclude salary as a regressor. Hausman test (Chi-squared=0.4098) favors again application of the parsimonious FEM (3).

Realized model regressions showed that both variables number of inhabitants and unemployment have effect on share of local taxes on current revenues. On the other hand, there is not statistically significant effect of number of inhabitants on share of local taxes on total revenues, which is also less sensitive to unemployment as share of local taxes on current revenues. FEM is most appropriate model in both cases as reported by Hausman tests. These models have the highest R-Squared, too.

\section{Discussions and Recommendations}

It would be dubious from us to argument on importance of local taxes for municipalities without having known the reality. Without being informed what is hidden behind the numbers. On one hand, we see the growing importance of local taxes for analysed municipalities: the share of local taxes on total incomes has grown within 2010-2013 in all municipalities. Those municipalities not investing huge capital confirm our hypothesis. On the other hand, high capital inflows mixed together with bank loans caused decreased share of local taxes on total incomes despite of their constant growth expressed in absolute numbers. Thus, in municipalities with the share of local taxes on total incomes below $20 \%$ we must reject our hypothesis.

Local taxes represent one of the important revenues for municipalities. As we see from provided analysis, the municipalities increased tax rates in order to strengthen own revenues and the budget structure. Incomes from local taxes serve mostly to cover current expenses. As seen from Table 2, their constant growth indicates the importance of local taxes for municipalities and vital financial source to provide widen volume of public services. In almost all analysed municipalities, the share of local taxes on current revenues exceeds $25 \%$ what demonstrates their growing importance for municipalities.

We point out to strong positive correlation between the development of local taxes and current revenues. We noticed increased current revenues when local taxes increased as well. But we cannot say that they increased in the same way. Since current revenues consist mostly from shared Income tax from natural persons (up to 60-65\%), they use to follow the shift upwards of the income tax transfer from state budget.

Finally, we confirm our hypothesis in municipalities which did not invest huge capital state or EU grants or bank loans to renew the infrastructure, to reconstruct or modernise sport, cultural, and social facilities. In those municipalities, the share of local taxes on total incomes was higher than $20 \%$. We decline our hypothesis in municipalities investing huge capital expenditures and receiving bank loans. The share of local taxes on total incomes is below $20 \%$. Despite the fact that share of local taxes on total incomes is below $20 \%$, they still remain significant source of own revenues and their increase is recommended and expected. Municipality of Prešov is the only single one to have the share below $20 \%$ during the analysed period. According to development of both absolute local taxes and the share of local taxes on total incomes in 2010-2013, we anticipate their increase in future periods.

We found positive correlation between the development of local taxes and total incomes as total incomes increased when the amount of local taxes grew in municipalities not investing huge capital or receiving bank loans. We found negative correlation between the development of local taxes and total incomes when total incomes decreased in municipalities investing huge capital or receiving bank loans despite the growth of local taxes. Although there is a 
correlation, these two categories did not shift in the same way.

Proposed municipalities' budgets for 2014-2015 confirm our recommendations for municipalities to keep on increasing the local tax rates. As mentioned in upper text, there is still free space to do so. The property taxes increased in Slovakia within 2004-2014 by 156\% but they still remain below the OECD and V4 countries' average.

The easiest way to increase the share of local taxes on total incomes is to decrease a comparison base: especially capital inflows and bank loans. But this progress would be misleading. It is not possible and it even would go against the basic principles of municipalities functioning and existence. Their main task is not only to maintain but also to build new and modernise the old property. It is impossible without capital investments. Therefore, the municipalities must focus on income structure and ways to increase it without influencing importance of the expenditure side.

\section{Conclusion}

In paper we focused on local taxes and their significance for Slovak municipalities. We analysed the development of local taxes in 2010-2013 in selected Slovak municipalities as well as their share on both current and total incomes. The aim of the paper was to prove the hypothesis: The share of local taxes on total incomes is above $20 \%$. We found different results for the municipalities and it is not possible to make clear single conclusion and confirmation. Final statements depend on decision of municipality representatives to invest to capital extensive infrastructure. Discussed conclusions and recommendations for municipalities are part of Chapter 4 . Stated goals were fulfilled.

\section{References}

Bánociová, A. (2011). Application of taxes in SR. ELFA - Košice, 193 p.

Bánociová, A.; Pavliková, L'. (2013). Application of econometric model in the studies of factors effecting the income tax of legal entity in the Slovak Republic. Journal of Applied Economic Sciences. Vol. 8, No. 2(24), p. 141-153.

Brunori, D.; Green, R.; Bell, M.; Choi, Ch.; Yuan, B. (2006), The Property Tax: Its Role and Significance in Funding State and Local Government Services. Available at http://www.gwu.edu/ gwipp/papers/wp027.pdf.

Clark, T.; Linzer, D. (2012), Should I Use Fixed or Random Effects? Working paper. Available at http://polmeth.wustl.edu/media/ Paper/ClarkLinzerREFEMar2012.pdf.

Croissant, Y.; Millo,G. (2008). Panel Data Econometrics in R: The plm Package. Journal of Statistical Software. Available at http://www.jstatsoft.org/v27/i02/paper.

Frees, E. W. (2004). Longitudinal and Panel Data: Analysis and Applications for the Social Sciences. Cambridge University Press. Available at http://instruction.bus.wisc.edu/ffrees/freesbooks/Longitudinal\%20and\%20Panel\%20Data/ BookebFeb2014/Chapters/ FreesFinal.pdf.

Gál, M. (2012). Financial analysis of municipalities in Slovakia. Tudományos Mozaik: 9. kötet: második rész. - Kalocsa : Tomori Pál Foiskola, p. 155-163.

Geys, B.; Revelli, F. (2009). Decentralization, Competition and the Local Tax Mix: Evidene from Flanders. Documents de Treball de $1^{1}$ IEB 2009/17. Available at http://ieb.ub.edu/aplicacio /fitxers/2009/10/Doc2009-17.pdf.

Maličká, L.; Horváth, J.; Gazda, V.; Kubák, M. (2012). Fiscal Decentralization and Public Debt in the European Union. Lex Localis : Journal of Local Self-Government. Vol. 10, No. 3, p. 265-276.

Neubauerová, E. (2009) Taxation (taxation theory and policy) Bratislava, p. 97.

R Core Team (2014). R: A language and environment for statistical computing. R Foundation for Statistical Computing. Available at http://www.r-project.org/.

Sotoláŕ, J. (2004) Act on property tax (commentary). Košice, p. 21.

Široký, J. (2008) Taxation theory with practical application. Prague, p. 165.

Act 369/1990 on municipality constitution.

Act 582/2004 on local taxes and local fee for communal waste.

Act 584/2004 on budgetary rules. 